\title{
EMISSION ESTIMATES ANDAIR QUALITY IMPACTS FROM THE USE OF ALTERNATIVE FUELS BY THE TITAN CEMENT FACTORY IN THESSALONIKI
}

\author{
N. MOUSSIOPOULOS ${ }^{1, *}$ \\ G. BANIAS ${ }^{2}$ \\ J. DOUROS ${ }^{1}$ \\ A.V. MICHAILIDOU ${ }^{1}$ \\ G. TSEGAS ${ }^{1}$
}

Received: 02/12/11

Accepted: 09/03/12

\author{
${ }^{1}$ Laboratory of Heat Transfer and Environmental Engineering \\ Department of Mechanical Engineering \\ Aristotle University of Thessaloniki, 54124 Thessaloniki, Greece \\ ${ }^{2}$ School of Economics and Business Administration \\ International Hellenic University, 57001 Thermi, Greece
}

*to whom all correspondence should be addressed:

e-mail: moussio@eng.auth.gr

\section{ABSTRACT}

Cement production is an energy-intensive process. Utilisation of fossil fuels is common practice in the cement industry around the world. Alternative fuel substitution rates increase every year. More specifically, $18 \%$ of the fuel used by the European cement industry in 2006 consists of alternative fuels. This study aims to investigate the prospects for the partial replacement of conventional fossil fuels currently used in the TITAN cement factory in Thessaloniki, Greece, with alternative fuels, focusing on the impact of alternative fuel use on the emissions of air pollutants from co-incineration operations. Air emissions were estimated for both the conventional fuel and mixtures of conventional fuel with alternative fuels, based on emission factors found in the literature but also using the measurements conducted by TITAN in 2010. Emission estimates indicate that legislative limit values for all pollutants are not exceeded. Based on the emission estimates and measurements in the flue gas, the dispersion of the plume around the factory has been described with an appropriate numerical simulation model. Results suggest that the factory's contribution to the air pollution levels in the surrounding area is very low for most regulated pollutants.

KEYWORDS: alternative fuels, cement industry, emission factors, air pollutant dispersion, AUSTAL 2000.

\section{INTRODUCTION}

Alternative fuels have been used in cement industry in order to replace fossil fuels during cement production in the majority of developed countries during the past 10 years. Japan, Switzerland, the U.S.A, Belgium, Germany and France play a leading role in alternative fuel use. The average substitution rates of alternative fuels in the European cement industry in 2006 reached $18 \%$ (Cembureau CSI, 2009). The purpose of this study is the estimation of air pollutant emissions, as well as the simulation of their dispersion in the area around the TITAN cement factory in Thessaloniki, Greece. The estimation was performed for five mixture scenarios of conventional fossil fuel (Pet coke) with alternative fuels and are compared with the present operational mode of the factory, i.e. the exclusive use of Pet coke as fuel (Business As Usual scenario-BAU).

The estimated emissions are compared with the limit values defined in European legislation regarding waste incineration and ambient air quality. More specifically, total emission limit values for cement kilns co-incinerating wastes are defined in Annex II paragraph II.1. of the Directive 2000/76/EC. Limit values for the use of Pet coke are defined in the Environmental Terms and Conditions (ETC) (2006) of the factory $\left(\mathrm{SO}_{2}: 400 \mathrm{mg} \mathrm{Nm}^{-3}, \mathrm{NO}_{2}: 1200 \mathrm{mg} \mathrm{Nm}^{-3}\right.$, dust: $50 \mathrm{mg} \mathrm{Nm}^{-3}$ ). Limits for ambient air quality are defined in Directive 2008/50/EC, whereas As, Cd, Ni and B(a)P emission limit values are defined in Directive 2004/107/EC.

The alternative fuels that were investigated are: (i) Alternative Solid Fuel (ASF) from Polyeco S.A., (ii) Residues from Packaging Recycling (RPR) (iii) Automotive Shredder Residue (ASR), (iv) Dry 
Sewage Sludge (DSS). The chemical composition of all alternative fuels was provided by the TITAN company. Each scenario ( $A$ to $E$ ) represents a mixture of Pet coke with one or more alternative fuels:

- BAU: Pet coke $100 \%$.

- Scenario A: Pet coke $70 \%$ - "DSS" $30 \%$.

- Scenario B: Pet coke $70 \%$ - "RPR" $30 \%$.

- Scenario C: Pet coke $70 \%$ - "ASF" $30 \%$.

- Scenario D: Pet coke $70 \%$ - "DSS" $10 \%$ - "RPR" $10 \%$ - "ASF" $10 \%$.

- Scenario E: Pet coke $70 \%$ - "ASR" $30 \%$

\section{METHODOLOGY}

In order to calculate the expected emissions of air pollutants from waste co-incineration in the factory, a detailed literature review was conducted. More specifically, for air pollutants, both in the form of gaseous species and particulate matter, including heavy metals, concentrations in the flue gas were calculated on the basis of the emission factors of the AP-42 US-EPA report (EPA, 1994). This report includes a qualitative assessment and classification of the provided data, which was used in order to utilize the most reliable data. Additionally, emissions of $\mathrm{NO}_{2}$ were calculated on the basis of an AEA Technology report which introduces a detailed emission factor review of the Cement Industry worldwide (AEAT, 2003). Due to the scarcity of available data, the emission estimates of HF for the BAU scenario were based solely on measurements of the TITAN company, conducted in 2010.

Emissions of air pollutants for scenarios $A$ to $E$ were calculated on the basis of international studies which indicate variations of the expected emissions during the combustion of alternative fuels. More specifically, the estimation of emission factors was based on the study of Richards et al. (2008), where the alternative fuel under study was the Tire-Derived Fuel (TDF). The emissions of $\mathrm{SO}_{2}, \mathrm{HCl}$ and HF were estimated on the basis of the sulfur, chlorine and fluorine content in the fuel. It should be noted however that real emissions of $\mathrm{HCl}$ and $\mathrm{HF}$ for the scenarios under consideration can be considerably lower than those estimated, due to the neutralization of the produced $\mathrm{HCl}$ and $\mathrm{HF}$ in the alkaline environment of the kiln. Nevertheless, the approach adopted represents the worst case scenario. No reliable data for the emission factors of benzene and $\mathrm{B}(\mathrm{a}) \mathrm{P}$ for alternative fuels were found. Therefore, a conservative approach was adopted, assuming that the emission factors of benzene and $\mathrm{B}(\mathrm{a}) \mathrm{P}$ are the same as those of Pet coke.

Regarding heavy metal emissions, the calculations for all scenarios were based on Kleppinger's (1993) study combined with the chemical composition of alternative fuels. It should be noted that the clinker generally acts as a sink for the majority of heavy metals added to the kiln, however the process can be described by the retention ratio of heavy metals both for clinker and the cement kiln dust. Those retention ratios in the aforementioned study were calculated on the basis of a series of six cement kilns tests ( 3 precalciner, 2 preheater and 1 wet). It is important to mention that the factory in Thessaloniki uses the dry method, with preheater and precalciner technology (ILC technology). Additionally, in order to estimate the emissions from the co-incineration of alternative fuels, the following assumptions were adopted: (i) Specific energy consumption: $3220.9 \mathrm{~kJ} \mathrm{~kg}^{-1}$, (ii) capacity: 4350 t clinker per day, (iii) Percentage of $\mathrm{PM}_{10}$ on the total emission of dust: $84 \%$ (USEPA, 1994), (iv) Selective Non-Catalytic Reduction System Efficiency Rate (SNCR) for limiting emissions of $\mathrm{NO}_{2}: 45 \%$.

Further to the estimation of emissions, the study also aimed to investigate the dispersion of air pollutants emitted by the factory for all fuel scenarios. The results of each scenario are then compared with the BAU scenario. For this purpose, the AUSTAL 2000 (Janicke et al., 2003; Janicke, 2002) dispersion model was utilized, in order to estimate the impact of the factory on the air pollution levels in the area near the stack. AUSTAL 2000 is a Lagrangian type model that was developed on behalf of the German Federal Environmental Service. The model takes into account the topography of the area under investigation by calculating air flow based on the TALdia diagnostic model. It should also be noted that in the calculations presented, no chemical transformations of the released pollutants were considered, with the exception of the oxidation of $\mathrm{NO}$ into $\mathrm{NO}_{2}$. The model was applied for a $10 \times 10 \mathrm{~km}^{2}$ region, its centre being the stack of the factory. The period of the application was a full calendar year (1997), which in the framework of the current study, was considered sufficient for presenting the variability of the meteorological conditions of the region with satisfactory 
accuracy. The required meteorological input data for the dispersion model were calculated with the aid of a downscaling methodology (Meteo-Generator), which was developed by the Laboratory of Heat Transfer and Environmental Engineering of AUTh and is capable of simulating meteorological parameters in user-defined locations across Europe for long time periods (Douros et al., 2009).

\section{RESULTS}

Emission estimates of air pollutants were based both on the emission factors adopted from the literature review as well as measurements of concentrations in the flue gas that became available to the research team by the TITAN company. Table 1 illustrates the literature based emission estimates for all air pollutants, leading to the following preliminary results:

- The measurements of air pollutant concentrations in the flue gas are lower compared to the calculations based on emission factors found in the literature. This could be due to the fact that emission factors found in the literature originate from measurements conducted in a series of cement kilns, using different technologies and fuels. Therefore, the operational characteristics of TITAN's cement kiln in conjunction with pollution abatement technologies in use, apparently place the company near the lower limit of literature estimates.

- $\mathrm{NO}_{2}$ emissions of the BAU scenario exceed the limit value for both the high and the average estimate. Exceedances also occur for the alternative fuel scenarios. Therefore, $\mathrm{NO}_{\mathrm{x}}$ abatement measures should be adopted, like the SNCR technology. Using a SNCR system with an efficiency rate of $45 \%$, leads to emission estimates for $\mathrm{NO}_{2}$ below the threshold set in theETC of the factory for the BAU scenario.

- Regarding dust emissions, the legislative limits are not exceeded, neither for the BAU scenario $\left(50 \mathrm{mg} \mathrm{Nm}^{-3}\right.$ ), nor for the scenarios of alternative fuels under consideration.

- In scenarios B, C, D, E both average and high emission estimates of $\mathrm{HCl}$ exceed the limit value. This is due to the high chlorine content of "RPR", "ASF" and "ASR".

- CO emissions are expected to increase by the use of alternative fuels based on the study of Richards et al. (2008), without exceedance of the emission limit value.

- Dioxin and furan emissions are below the limit value.

- Exceedances of the limit value occur for high emission estimates of $\mathrm{Hg}$ in scenarios $A, B, D$ and $\mathrm{E}$. These exceedances are due to the higher $\mathrm{Hg}$ content of "DSS", "RPR" and "ASR" in comparison with $\mathrm{Hg}$ content of Pet coke.

- Total emissions for heavy metals $(\mathrm{Sb}+\mathrm{As}+\mathrm{Pb}+\mathrm{Cr}+\mathrm{Co}+\mathrm{Cu}+\mathrm{Mn}+\mathrm{Ni}+\mathrm{V})$ exceed the legislative limit value in Scenario C for the high estimate, due to high $\mathrm{Pb}$ and Mn content in "ASF".

As already mentioned, emissions from cement kilns can be affected by a number of factors, including the particular kiln design, the type of burner, raw materials, fuels, how and where the fuels are introduced into the kiln, the way in which the kiln operates (e.g. percentage of excess air, retention times), and the specifications of the final product. On this ground, emission estimates could alternatively be calculated based on flue gas measurements for the year 2010 , considering that these measurements are representative for the operation of TITAN cement factory in Thessaloniki (Table 2). 
Table 1. Emission estimates of air pollutants, based on the literature review

\begin{tabular}{|c|c|c|c|c|c|c|c|c|c|c|c|c|c|c|c|}
\hline & \multicolumn{4}{|c|}{ BAU } & \multicolumn{2}{|c|}{ Scenario A } & \multicolumn{2}{|c|}{ Scenario B } & \multicolumn{2}{|c|}{ Scenario C } & \multicolumn{2}{|c|}{ Scenario D } & \multicolumn{2}{|c|}{ Scenario E } & \multirow[b]{2}{*}{$\begin{array}{l}\text { Legislative } \\
\text { limit } \\
\text { values } \\
\left(\mathrm{mg} \mathrm{Nm}^{-3}\right)\end{array}$} \\
\hline & $\begin{array}{l}\text { High } \\
\text { estimate } \\
\left(\mathrm{mg} \mathrm{Nm}^{-3}\right)\end{array}$ & $\begin{array}{l}\text { Average } \\
\text { estimate } \\
\left(\mathrm{mg} \mathrm{Nm}^{-3}\right)\end{array}$ & $\begin{array}{c}\text { Measure- } \\
\text { ment } \\
2010 \\
\left(\mathrm{mg} \mathrm{Nm}^{-3}\right)\end{array}$ & $\begin{array}{c}\text { ETC } \\
\left(\mathrm{mg} \mathrm{Nm}^{-3}\right)\end{array}$ & $\begin{array}{l}\text { High } \\
\text { estimate } \\
\left(\mathrm{mg} \mathrm{Nm}^{-3}\right)\end{array}$ & $\begin{array}{l}\text { Average } \\
\text { estimate } \\
\left(\mathrm{mg} \mathrm{Nm}^{-3}\right)\end{array}$ & $\begin{array}{l}\text { High } \\
\text { estimate } \\
\left(\mathrm{mg} \mathrm{Nm}^{-3}\right)\end{array}$ & $\begin{array}{l}\text { Average } \\
\text { estimate } \\
\left(\mathrm{mg} \mathrm{Nm}^{-3}\right)\end{array}$ & $\begin{array}{l}\text { High } \\
\text { estimate } \\
\left(\mathrm{mg} \mathrm{Nm}^{-3}\right)\end{array}$ & $\begin{array}{l}\text { Average } \\
\text { estimate } \\
\left(\mathrm{mg} \mathrm{Nm}^{-3}\right)\end{array}$ & $\begin{array}{c}\text { High } \\
\text { estimate } \\
\left(\mathrm{mg} \mathrm{Nm}^{-3}\right)\end{array}$ & $\begin{array}{l}\text { Average } \\
\text { estimate } \\
\left(\mathrm{mg} \mathrm{Nm}^{-3}\right)\end{array}$ & $\begin{array}{l}\text { High } \\
\text { estimate } \\
\left(\mathrm{mg} \mathrm{Nm}^{-3}\right)\end{array}$ & $\begin{array}{l}\text { Average } \\
\text { estimate } \\
\left(\mathrm{mg} \mathrm{Nm}^{-3}\right)\end{array}$ & \\
\hline $\mathrm{SO}_{2}^{(1)}$ & 46.12 & 43.2 & 5.5 & 400 & 36.61 & 34.56 & 40.93 & 38.88 & 40.93 & 38.88 & 39.49 & 37.44 & 38.01 & 36 & 50 \\
\hline $\mathrm{NO}_{2}{ }^{(2)}$ & 2036.6 & 1071.9 & 839.1 & 1200 & 1822.8 & 959.4 & 1822.8 & 959.4 & 1822.8 & 959.4 & 1822.8 & 959.4 & 1822.8 & 959.4 & 800 \\
\hline $\mathrm{NO}_{2}$ withSNCR ${ }^{(3)}$ & 1120.1 & 589.5 & - & - & 1002.5 & 527.6 & 1002.5 & 527.6 & 1002.5 & 527.6 & 1002.5 & 527.6 & 1002.5 & 527.6 & 800 \\
\hline Dust $^{(1)}$ & 26.06 & 19.16 & 0.6 & 50 & 23.33 & 17.15 & 23.33 & 17.15 & 23.33 & 17.15 & 23.33 & 17.15 & 23.33 & 17.15 & 30 \\
\hline $\mathrm{PM}_{10}{ }^{(1)}$ & 21.89 & 16.1 & 0.6 & - & 19.59 & 14.41 & 19.59 & 14.41 & 19.59 & 14.41 & 19.59 & 14.41 & 19.59 & 14.41 & \\
\hline $\mathrm{HCl}^{(1)}$ & 3.12 & 1.95 & 0.965 & - & 9.95 & 6.22 & 29.34 & 18.34 & 21.59 & 13.49 & 20.29 & 12.69 & 29.34 & 18.34 & 10 \\
\hline HF & 0.204 & 0.1274 & 0.1274 & - & 0.976 & 0.61 & 0.976 & 0.61 & 0.976 & 0.61 & 0.976 & 0.61 & 0.976 & 0.61 & 1 \\
\hline Benzene $^{(1)}$ & 3.1 & 2.6 & 0.526 & - & 3.1 & 2.6 & 3.1 & 2.6 & 3.1 & 2.6 & 3.1 & 2.6 & 3.1 & 2.6 & \\
\hline$B(a) P^{(1)}$ & $2.76 \cdot 10^{-5}$ & $2.11 \cdot 10^{-5}$ & - & - & $2.76 \cdot 10^{-5}$ & $2.11 \cdot 10^{-5}$ & $2.76 \cdot 10^{-5}$ & $2.11 \cdot 10^{-5}$ & $2.76 \cdot 10^{-5}$ & $2.11 \cdot 10^{-5}$ & $2.76 \cdot 10^{-5}$ & $2.11 \cdot 10^{-5}$ & $2.76 \cdot 10^{-5}$ & $2.11 \cdot 10^{-5}$ & \\
\hline $\mathrm{CO}^{(1)}$ & 1786.5 & 1429.2 & 160 & - & 2000.9 & 1600.7 & 2000.9 & 1600.7 & 2000.9 & 1600.7 & 2000.9 & 1600.7 & 2000.9 & 1600.7 & \\
\hline PCDD/Fs ${ }^{(1)}$ & $4.87 \cdot 10^{-8}$ & $4.55 \cdot 10^{-8}$ & $1.54 \cdot 10^{-8}$ & - & $3.92 \cdot 10^{-8}$ & $3.66 \cdot 10^{-8}$ & $3.92 \cdot 10^{-8}$ & $3.66 \cdot 10^{-8}$ & $3.92 \cdot 10^{-8}$ & $3.66 \cdot 10^{-8}$ & $3.92 \cdot 10^{-8}$ & $3.66 \cdot 10^{-8}$ & $3.92 \cdot 10^{-8}$ & $3.66 \cdot 10^{-8}$ & $10^{-7}$ \\
\hline $\mathrm{Hg}^{(4)}$ & 0.021 & 0.011 & 0.017 & - & 0.057 & 0.031 & 0.061 & 0.033 & 0.047 & 0.026 & 0.055 & 0.03 & 0.054 & 0.029 & 0.05 \\
\hline$C d+T^{(4)}$ & 0.006 & 0.003 & 0.0022 & - & 0.013 & 0.007 & 0.015 & 0.008 & 0.011 & 0.006 & 0.013 & 0.007 & 0.014 & 0.007 & 0.05 \\
\hline $\begin{array}{l}\mathrm{Sb}+\mathrm{As}+\mathrm{Pb}+\mathrm{Cr}+ \\
\mathrm{Co}+\mathrm{Cu}+\mathrm{Mn}+\mathrm{Ni}+\mathrm{V}^{(4)}\end{array}$ & 0.016 & 0.008 & 0.0106 & - & 0.363 & 0.102 & 0.41 & 0.11 & 0.7 & 0.23 & 0.49 & 0.14 & 0.43 & 0.12 & 0.5 \\
\hline
\end{tabular}

\footnotetext{
(1) U. S. Environmental Protection Agency (US-EPA), 1994. Emission Factor Documentation for AP-42, Section 11.6, Portland Cement Manufacturing, Final Report, May.

${ }^{(2)}$ AEA Technology (AEAT), 2003.Emission factors programme Task 4(b) - Review of cement sector Pollution Inventory Report to the Department for Environment, Food and Rural Affairs; the National Assembly of Wales: the Scottish Executive; and the Department of Environment in Northern Ireland, AEAT/ENV/R/1425/lssue, August.

(3) Schreiber and Yonley Associates, 2008.CurrentState of Practice for Selective Non-Catalytic Reduction, Portland Cement Association,PCA R\&D Serial No. 3046.

${ }^{(4)}$ Kleppinger E.W., 1993. Cement clinker: an environmental sink for residues from hazardous waste treatment in cement kilns, Waste Management 13 (8), $553-572$.
} 
Table 2. Average emission estimates of air pollutants, aerosols and heavy metals based on TITAN measurements

\begin{tabular}{|c|c|c|c|c|c|c|c|c|}
\hline $\mathrm{mg} \mathrm{Nm}^{-3}$ & $\begin{array}{l}\text { Measurement } \\
2010 \\
\end{array}$ & ETC & Scenario A & Scenario B & Scenario C & Scenario D & Scenario E & $\begin{array}{l}\text { Legislative } \\
\text { limit values }\end{array}$ \\
\hline $\mathrm{SO}_{2}$ & 5.5 & 400 & 4.4 & 4.95 & 4.95 & 4.767 & 4.583 & 50 \\
\hline $\mathrm{NO}_{2}$ & 839.1 & 1200 & 751 & 751 & 751 & 751 & 751 & 800 \\
\hline Dust & 0.6 & 50 & 0.537 & 0.537 & 0.537 & 0.537 & 0.537 & 30 \\
\hline $\mathrm{PM}_{10}$ & 0.6 & & 0.537 & 0.537 & 0.537 & 0.537 & 0.537 & \\
\hline $\mathrm{HCl}$ & 0.965 & & 3.078 & 9.084 & 6.682 & 6.281 & 9.084 & 10 \\
\hline $\mathrm{HF}$ & 0.1274 & & 0.61 & 0.61 & 0.61 & 0.61 & 0.61 & 1 \\
\hline Benzene & 0.526 & & 0.526 & 0.526 & 0.526 & 0.526 & 0.526 & \\
\hline$B(a) P$ & - & & - & - & - & - & - & \\
\hline $\mathrm{CO}$ & 160 & & 179.2 & 179.2 & 179.2 & 179.2 & 179.2 & \\
\hline PCDD/Fs & $1.54 \times 10^{-8}$ & & $1.24 \times 0^{-8}$ & $1.24 \times 10^{-8}$ & $1.24 \times 10^{-8}$ & $1.24 \times 10^{-8}$ & $1.24 \times 10^{-8}$ & $10^{-7}$ \\
\hline $\mathrm{Hg}$ & 0.017 & & 0.046 & 0.049 & 0.038 & 0.044 & 0.044 & 0.05 \\
\hline $\mathrm{Cd}+\mathrm{TI}$ & 0.0022 & & 0.005 & 0.005 & 0.004 & 0.005 & 0.005 & 0.05 \\
\hline \multicolumn{9}{|l|}{$\mathrm{Sb}+\mathrm{As}+\mathrm{Pb}+\mathrm{Cr}$} \\
\hline $\begin{array}{l}+\mathrm{Co}+\mathrm{Cu}+\mathrm{Mn}+ \\
\mathrm{Ni}+\mathrm{V}\end{array}$ & 0.0106 & & 0.139 & 0.157 & 0.309 & 0.201 & 0.165 & 0.5 \\
\hline
\end{tabular}

It is again worth mentioning that the operation of the factory on alternative fuel mixtures, leads to lower emissions for the majority of air pollutants.

As it can clearly be seen in Table 2, calculating emissions on the basis of flue gas measurements, eliminates most cases of exceedances. Alternative fuels appear to have higher emissions only in the cases of $\mathrm{HCl}, \mathrm{HF}$ and heavy metals. It should be noted that $\mathrm{B}(\mathrm{a}) \mathrm{P}$ emissions could not be estimated because of lack of measurements.

The effects on the local air pollution situation due to the operation of the factory were assessed focusing on the changes in air pollutants concentrations for the various fuel scenarios. It should be noted that in order to perform the dispersion simulations, plume rise was also taken into account, a phenomenon which is strongly related to the meteorological conditions prevailing over the area of study, as well as the temperature and speed of gases injected into the atmosphere through the stack. The parameters which were used in order to calculate plume rise are presented in Table 3.

Table 3. Geometrical characteristics and operational parameters of the stack

\begin{tabular}{lcc}
\hline \multicolumn{1}{c}{ Parameter } & Value & Unit \\
\hline Stack height & 124 & $\mathrm{~m}$ \\
\hline Stack diameter & 3,2 & $\mathrm{~m}$ \\
\hline Stack surface & 8,04 & $\mathrm{~m}^{2}$ \\
\hline Flue gas flow rate & 144 & $\mathrm{~m}^{3} \mathrm{~s}^{-1}$ \\
\hline Flue gas temperature & 110 & ${ }^{\circ} \mathrm{C}$ \\
\hline
\end{tabular}

The results of the calculations indicate that the contribution of the factory to the air pollution levels in the surrounding area is very low for all regulated pollutants, with the exception of $\mathrm{NO}_{2}$. For this pollutant and under particularly unfavourable meteorological conditions it is possible that the operation of the factory may lead to hourly concentrations comparable to the limit values set by the European legislation. The factory's air quality impact is lower for all alternative fuel scenarios investigated, with the exception of $\mathrm{HCl}, \mathrm{HF}, \mathrm{CO}$ and the heavy metals, where small increases are encountered, yet without limit value exceedances. 
Table 4. Maximum (within the study area) calculated concentration differences between scenario A and BAU

\begin{tabular}{|c|c|c|c|}
\hline $\begin{array}{l}\text { Pollutant } \\
\left.(\mu \mathrm{g} \mathrm{m})^{-3}\right)\end{array}$ & $\begin{array}{l}\text { Mean annual } \\
\text { concentration }\end{array}$ & $\begin{array}{l}\text { Maximum daily } \\
\text { concentration }\end{array}$ & $\begin{array}{l}\text { Maximum hourly } \\
\text { concentration }\end{array}$ \\
\hline $\mathrm{NO}_{\mathrm{x}}$ & -0.292 & & \\
\hline $\mathrm{SO}_{2}$ & -0.011 & -0.38 & -2.29 \\
\hline $\mathrm{NO}_{2}$ & -0.089 & & -51.4 \\
\hline $\mathrm{NO}_{2}$ (SNCR) & -0.048 & & -28.3 \\
\hline Dust & -0.003 & -0.11 & \\
\hline $\mathrm{PM}_{10}$ & -0.002 & -0.09 & \\
\hline $\mathrm{HCl}$ & 0.007 & 0.27 & \\
\hline HF & $8.8 \times 10^{-4}$ & 0.031 & \\
\hline $\mathrm{B}(\mathrm{a}) \mathrm{P}\left(\mathrm{ng} \mathrm{m}^{-3}\right)$ & $-1.1 \times 10^{-8}$ & & \\
\hline $\mathrm{CO}$ & 0.244 & 8.59 & \\
\hline PCDD/Fs $\left(\mathrm{fg} \mathrm{m}^{-3}\right)$ & -0.010 & -0.38 & \\
\hline $\mathrm{Pb}$ & $2.381 \times 10^{-5}$ & & \\
\hline As $\left(\operatorname{ng~m}^{-3}\right)$ & 0.001 & & \\
\hline $\operatorname{Cd}\left(\mathrm{ng} \mathrm{m}^{-3}\right)$ & 0.009 & & \\
\hline $\mathrm{Ni}\left(\mathrm{ng} \mathrm{m}^{-3}\right)$ & 0.002 & & \\
\hline
\end{tabular}

Table 4 presents differences between the maximum (within the study area) concentrations in scenario $A$ and $B A U$, while figure 1 presents indicative concentration maps for $\mathrm{PM}_{10}$ and $\mathrm{NO}_{2}$ as regards the base case scenario.
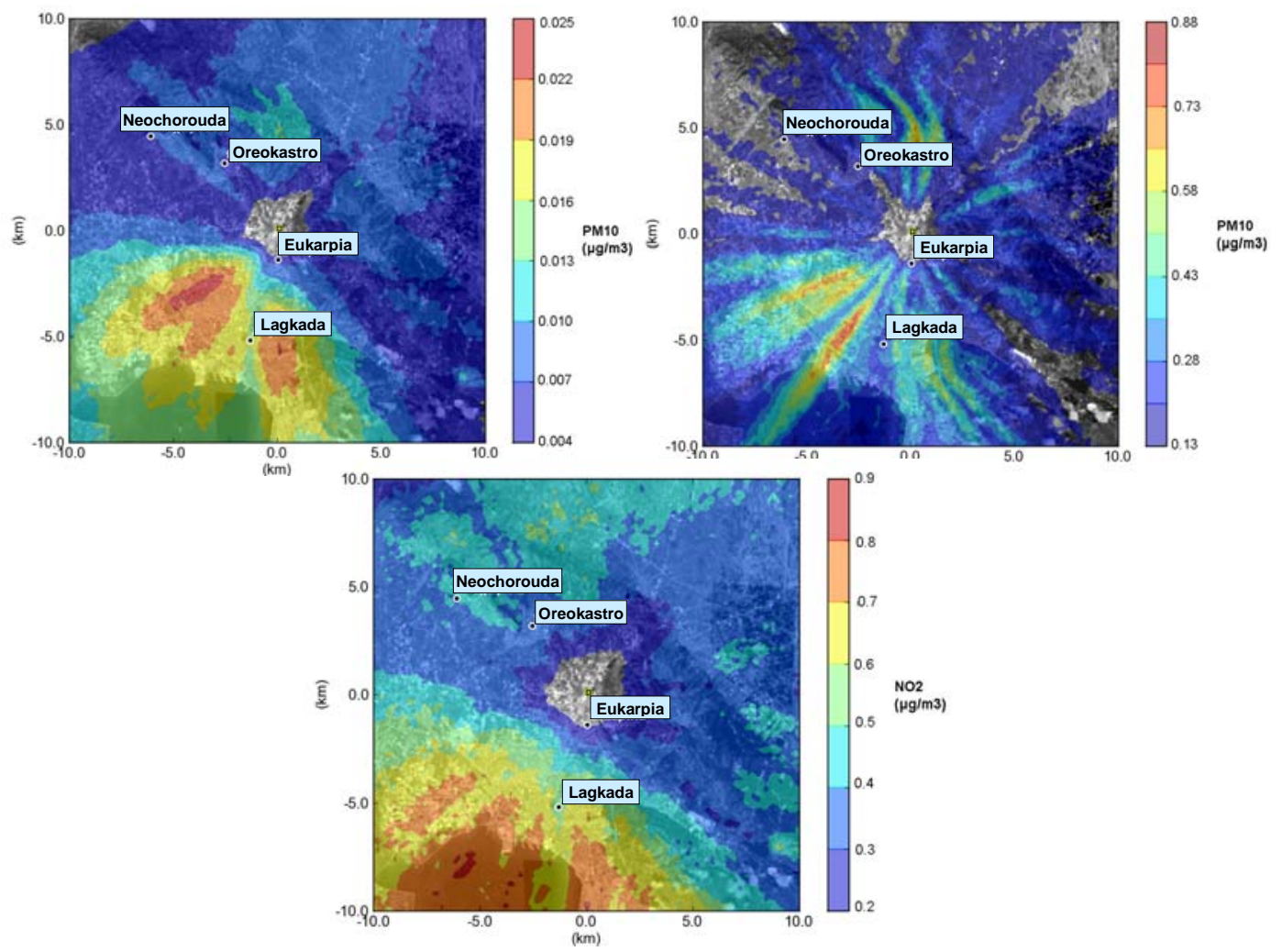

Figure 1. Spatial distribution of the factory contribution to the mean annual $\mathrm{PM}_{10}$ concentrations (upper left), the maximum daily average $\mathrm{PM}_{10}$ concentration (upper right) and the mean annual $\mathrm{NO}_{2}$ concentrations (lower) as regards the BAU scenario 


\section{CONCLUSIONS}

The present study is an attempt to estimate emissions as well as pollutant dispersion when alternative fuels are co-incinerated in the TITAN cement factory in Thessaloniki. The main conclusion of the investigation was that the use of alternative fuels leads generally to reductions in air pollutant emissions. Additional estimates based on flue gas measurements are below the emission limit values set by legislation. Calculations of the dispersion of pollutants and the factory's air quality impact in the area surrounding the stack, indicate that the contribution of the factory is very low for all scenarios under study.

Measurements in the flue gas of the Thessaloniki factory imply remarkably lower emissions than air pollutant emission estimates based on literature. Irrespective of this, it is recommended to continuously monitor the emission of air pollutants in the flue gas. This would allow an immediate identification of emission limit exceedances, for defining necessary adjustments in the production processes of the factory. For the emissions to stay below the limits foreseen by the legislation, in the case of a detected exceedanceit would be possible to either define more stringent standards of the alternative fuels' chemical composition and/or to modify the substitution rates of alternative fuel in the proposed mixtures.

\section{REFERENCES}

AEA Technology (AEAT), (2003), Emission factors programme Task 4(b) - Review of cement sector Pollution Inventory Report to the Department for Environment, Food and Rural Affairs; the National Assembly of Wales: the Scottish Executive; and the Department of Environment in Northern Ireland, AEAT/ENV/R/1425/Issue, August.

Cembureau C.S.I., (2009), Sustainable cement production: Co-Processing of alternative fuels and raw materials in the European Cement Industry.http://www.cembureau.be/topics/alternative-fuels-rawmaterials/alternative-fuels. (Last visited on 28/01/2012).

Douros I., Tsegas G. and Naneris C. (2009), Technical paper 1.3 - RS1b - Report on sub-grid atmospheric dispersion models. http://www.docstoc.com/docs/23011539/Near-real-time-data-exchange-system\#

Janicke L. (2002), Lagrangian dispersion modelling, Particulate Matter in and from Agriculture, 235, 3741, Hinz T., Ronnpagel B. and Linke S.

Janicke L. and Janicke U. (2003), (A modelling system for licensing industrial facilities) Entwicklung eines modellgestutzten Beurteilungssystems furden anlagenbezogenen Immissionsschutz. UFOPLAN 20043 256, on behalf of the German Federal Environmental Agency (UBA).

Kleppinger E. (1993), Cement clinker: an environmental sink for residues from hazardous waste treatment in cement kilns, Waste Management, 13(8), 553-572.

Richards J., Goshaw D., Speer D. and Holder T., (2008), Air Emissions Data Summary for Portland Cement Pyroprocessing Operations Firing Tire-Derived Fuels, Serial No. 3050, Portland Cement Association, Skokie Illinois.

U.S. Environmental Protection Agency (US-EPA), (1994), Emission Factor Documentation for AP-42, Section 11.6, Portland Cement Manufacturing, Final Report, MRI Project No. 4601-01

Schreiber and Yonley Associates, (2008), Current State of Practice for Selective Non-Catalytic Reduction, Portland Cement Association, PCA R\&D Serial No. 3046. 